\title{
SEMANGAT KERJA DAN PELAKSANAAN ASUHAN KEPERAWATAN DI RUMAH SAKIT UMUM KOLAKA SULAWESI TENGGARA
}

\author{
Zulaeni Esita \\ Fakultas Psikologi Universitas Merdeka Malang
}

\begin{abstract}
The implementation of nursing care that has not been done optimally, it has became a common problem in the most of government hospitals in Indonesia. Many customers feel not dissatisfied for health care services received from government hospitals. Work motivation is considered as one of the factors that influence the implementation of nursing care in hospital. It is can provide quality health services in hospital which expected by customers. The focus of this study was about how influence of Work motivation to the implementation of nursing care, especially in the Rumah Sakit Umum (RSU)Kolaka in Southeast Sulawesi. The study was designed as a quantitative. The population in this study were all nurses who worked at the RSU Kolaka. All the population in this study were the civil servants (PNS).The sampling technique used was purposive random sampling, so that the sample used in this research consisted of 53 nurses. Analysis of the data used was a simple linear regression analysis. The results of study showed thatthe work motivation contributed $15.6 \%$ to the implementation of nursing care $\left(\mathrm{R}^{2}=0.156\right)$ in the RSU Kolaka Southeast Sulawesi.
\end{abstract}

Keywords: nursing care, morale.

\begin{abstract}
ABSTRAK
Masalah umum pada sebagian besar rumah sakit pemerintah di Indonesia adalah pelaksanaan asuhan keperawatan yang belum terlaksana secara optimal. Sehingga pasien kerapkali merasa kurang puas karena belum terpenuhinya harapan atau keinginan pasien dalam menerima jasa pelayanan kesehatan. Semangat kerja dianggap sebagai salah satu faktor yang mempengaruhi pelaksanaan asuhan keperawatan dalam memberikan kualitas pelayanan kesehatan yang diharapkan oleh pasien. Karena itu fokus penelitian ini adalah melihat seberapa besar kontribusi pengaruh semangat kerja terhadap pelaksanaan asuhan keperawatan khususnya di Rumah Sakit Umum Kolaka Sulawesi Tenggara. Penelitian dirancang secara kuantitatif yang menggunakan populasi semua perawat yang bekerja di Rumah Sakit Umum Kolaka yang berstatus pegawai negeri sipil (PNS). Teknik sampling yang digunakan adalah purposive random sampling, terdiri dari 53 orang perawat PNS di Rumah Sakit Umum Kolaka. Analisis data yang digunakan adalah analisis regresi linear sederhana. Hasil penelitian menunjukkan bahwa semangat kerja memberikan sumbangan sebesar $15,6 \%$ terhadap pelaksanaan asuhan keperawatan $\left(R^{2}=0,156\right)$ di Rumah Sakit Umum Kolaka Sulawesi Tenggara.
\end{abstract}

Kata kunci: Asuhan keperawatan, semangat kerja. 


\section{PENDAHULUAN}

Kesehatan merupakan salah satu kebutuhan manusia yang tidak bisa dipandang sebelah mata lagi oleh individu. Kesehatan merupakan salah satu kebutuhan individu yang menuntut untuk segera dipenuhi, semakin banyaknya kerusakankerusakan yang terjadi di muka bumi ini yang berdampak pada kesehatan manusia menyebabkan timbulnya berbagai penyakit baru yang beragam. Layanan jasa rumah sakit, merupakan suatu layanan masyarakat yang penting dan dibutuhkan dalam upaya pemenuhan tuntutan kesehatan tersebut. Banyaknya rumah sakit rumah sakit swasta yang tumbuh dan berkembang di sekitar rumah sakit rumah sakit pemerintah yang ada merupakan salah satu bukti bahwa semakin berkembangnya usaha pelayanan jasa di bidang ini. Hal ini menyebabkan rumah sakit yang ada saling berkompetisi dalam meningkatkan mutu dan kualitas pelayanannya guna menarik klien dalam hal ini sebagai customer dalam pelayanan jasa ini. Salah satu upaya yang dilakukan oleh rumah sakit untuk menarik customer adalah dengan memberikan pelayanan prima jasa kesehatan.

Banyak unsur yang berperan dan mendukung berfungsinya pelayanan prima jasa kesehatan. Salah satu unsur utama pendukung tersebut adalah sumber daya manusia (SDM) yang berkualitas tinggi dan disertai kesadaran akan penghayatan pengabdian kepada kepentingan masyarakat, khususnya dalam pemenuhan kebutuhan layanan kesehatan termasuk di dalamnya adalah optimalisasi asuhan keperawatan terhadap klien atau pengguna jasa kesehatan.

Asuhan keperawatan merupakan upaya untuk membantu individu, baik sakit maupun sehat, dari lahir sampai meninggal dunia, dalam bentuk peningkatan pengetahuan dan kemampuan yang dimiliki sehingga individu tersebut dapat secara optimal melakukan kegiatan sehari-hari secara mandiri (Ali, 2002). Proses atau rangkaian kegiatan praktik keperawatan yang langsung diberikan kepada klien/pasien, pada berbagai tatanan pelayanan kesehatan dengan menggunakan metodologi proses keperawatan, berpedoman pada standar keperawatan, dilandasi etik dan etika keperawatan, dalam lingkup wewenang serta tanggung jawab keperawatan didefinisikan sebagai asuhan keperawatan (Kusnanto, 2004). Secara umum asuhan keperawatan diartikan sebagai suatu bentuk pelayanan keperawatan kepada pasien yang bersifat humanistik, caring, professional, dan holistik yang diberikan secara langsung pada individu, keluarga dan masyarakat baik sakit maupun sehat yang berpedoman pada standar keperawatan dalam bentuk peningkatan pengetahuan dan kemampuan yang dimiliki sehingga pasien tersebut dapat secara optimal melakukan kegiatan sehari-hari secara mandiri (Ali, 1999; Ali, 2002; Kusnanto, 2004).

Menurut Depkes RI (dalam Purwanto, 2007) ada aspek-aspek dasar yang menjadi komponenkomponen asuhan keperawatan, diantaranya adalah: 1). Aspek 
penerimaan, meliputi sikap perawat yang selalu ramah, periang, selalu tersenyum, menyapa semua pasien, memiliki minat terhadap orang lain, menerima pasien tanpa membedakan golongan, pangkat, latar belakang sosial ekonomi dan budaya. 2). Aspek perhatian (caring), meliputi sikap sabar, bersedia memberikan bantuan dan pertolongan kepada pasien dengan sukarela tanpa mengharapkan imbalan, memiliki sensitivitas dan peka terhadap setiap perubahan pasien, mau mengerti terhadap kecemasan dan ketakutan pasien. 3). Aspek komunikasi, meliputi sikap berkomunikasi yang baik dengan pasien dan keluarga pasien, adanya hubungan yang baik dengan keluarga pasien. 4). Aspek kerja sama, meliputi sikap perawat yang harus mampu melakukan kerjasama yang baik dengan pasien dan keluarga pasien. 5). Aspek tanggung jawab, meliputi sikap perawat yang jujur, tekun dalam tugas, mampu mencurahkan waktu dan perhatian, sportif dalam tugas, konsisten serta tepat dalam bertindak.

Asuhan keperawatan ini merupakan bentuk pelayanan profesional yang bertujuan untuk membantu klien dalam pemulihan dan peningkatan kemampuan dirinya melalui tindakan pemenuhan kebutuhan klien secara komprehensif dan berkesinambungan sampai klien mampu untuk melakukan kegiatan rutinitasnya tanpa bantuan dari seorang perawat (Ali, 2002). Bentuk pelayanan ini seyogyanya diberikan oleh perawat yang memiliki kemampuan serta sikap dan kepribadian yang sesuai dengan tuntutan profesi keperawatan, dan untuk itu tenaga keperawatan ini harus dipersiapkan dan ditingkatkan secara teratur, terencana, dan berkesinambungan.

Terlaksananya asuhan keperawatan secara optimal memberikan dampak yang positif bagi institusi, salah satunya adalah dengan terciptanya layanan kesehatan yang bermutu dan berkualitas dari sumber daya manusia yang memberikan hasil kerja yang baik terhadap institusinya, baik secara kualitas ataupun secara kuantitas demi tercapainya tujuan organisasi atau institusi.Pelaksanaan asuhan keperawatan ini oleh perawat belum dijadikan sebagai kewajiban utama dalam melaksanakan tugas mereka. Sebagian perawat masih ada yang memberikan asuhan keperawatan kepada klien tidak sebagaimana mestinya sehingga sering terjadi kesalahan dalam mengambil keputusan untuk menyelesaikan masalah klien. Kondisi tersebut menyebabkan pelayanan kesehatan dianggap belum berkualitas karena pasien sebagian besar merasakan ketidakpuasan terhadap pelayanan kesehatan yang ada, begitu pula yang terjadi pada Rumah Sakit Umum Kolaka Sulawesi Tenggara.

Rumah Sakit Umum Kolaka berada di kabupatenKolaka, propinsi Sulawesi Tenggara. Rumah Sakit Umum Kolaka secara organisatoris berada di bawah naungan Pemerintah Daerah Tingkat II Kolaka yang bertugas melaksanakan upaya pelayanan kesehatan masyarakat dan pelayanan rujukan dalam wilayah Kabupaten Kolaka yang berpenduduk \pm 47.703 jiwa dengan tingkat pertumbuhan penduduk rata-rata $3,08 \%$ per tahun. Pemanfaatan RSU 
ini dimulai pada bulan Juni 1980 dengan hanya memiliki satu bangunan, namun saat ini RSU Kolaka di bawah pimpinan dr. Muhammad Junaid, Sp.B, mulai mengembangkan diri dengan membangun dan meningkatkan sarana dan prasarananya sehingga saat ini telah memiliki 17 bangunan.

Rumah sakit ini merupakan salah satu rumah sakit pemerintah tipe $\mathrm{C}$, dimana sumber daya yang dimiliki baik SDM maupun fasilitas masih sangat terbatas. Keterbatasan tersebut ditunjukkan dengan keberadaan dokter ahli yang ada saat ini hanya terdapat lima (5) orang yaitu: spesialis penyakit dalam 1 orang, spesialis bedah 1 orang, spesialis saryaf 1 orang, spesialis obstretri \& gynekologi 1 orang dan 1 orang spesialis anak. Rumah sakit ini juga hanya memiliki empat dokter umum, dua dokter gigi, dan seorang apoteker. Sarana dan prasarana yang dimiliki pun masih cukup terbatas jumlahnya, untuk sarana RSU ini hanya memiliki 18 unit gedung dengan rincian; 4 gedung perawatan rawat inap, 1 gedung administrasi, 1 gedung bedah (kamar operasi), 1 gedung poliklinik umum (rawat jalan), 1 gedung poliklinik dokter ahli, 1 gedung laboratorium, 1 gedung radiologi, 1 gedung UGD (Unit Gawat Darurat), 1 gedung genset, 1 gedung gizi, 1 gedung mayat (kamar mayat), 1 gedung farmasi, 1 gedung konseling dokter ahli, dan 1 gedung pertemuan. Prasarana yang saat ini dimiliki oleh rumah sakit ini adalah 2 set peralatan bedah, 1 set peralatan anak, 1 set peralatan THT, 2 set peralatan kebidanan, gynekologi bed 2 unit, peralatan gigi 2 set, peralatan rehabilitasi medik 1 set, ada 1 unit peralatan $x$-ray, peralatan incenerator 1 unit, 2 unit peralatan ahli dalam, sterilizer 2 unit, ICU bed 4 set, patient monitor 2 unit, infusion pump 1 unit, syringe pump 1 unit, suction pump 2 unit, pulse oxymetri 2 unit, peralatan ahli syaraf 2 unit, hospital bed (backrest-adjustable) 8 unit, komputer 9 unit, printer 3 unit, genset 2 unit, ambulance ada 4 unit, mobil UTD 1 unit, dan 10 kendaraan dinas yang terdiri dari, 5 buah mobil dinas dokter ahli dan 5 buah motor dinas.

Masalah umum pada sebagian besar rumah sakit pemerintah di Indonesia yang ada adalah pelaksanaan asuhan keperawatan yang belum terlaksana secara optimal, sehingga pasien kerapkali merasa kurang puas atas jasa pelayanan kesehatan yang diberikan oleh rumah sakit pemerintah. Disisi lain, pihak swasta mengambil kesempatan peluang bisnis di bidang jasa kesehatan ini dengan mendirikan rumah sakit-rumah sakit swasta dan memberikan pelayanan berupa pelaksanaan asuhan keperawatan yang optimal sesuai dengan harapan dan keinginan pasien sebagai konsumen, serta dilengkapi dengan fasilitas kesehatan yang lebih memadai. Hal ini secara tidak langsung menjadi ancamam bagi keberadaan rumah sakit pemerintah.

Rumah Sakit Umum Kolaka Sulawesi Tenggara merupakan salah satu rumah sakit pemerintah yang pelaksanaan asuhan keperawatannya belum berjalan secara optimal sehingga, sebagian besar pasien ataupun mereka yang pernah menjadi pasien di rumah sakit tersebut merasa belum memperoleh kepuasan 
terhadap pelayanan jasa kesehatan yang diberikan oleh pihak rumah sakit. Pelaksanaan asuhan keperawatan yang belum optimal inilah yang menjadi salah satu penyebab belum tercapainya tujuan organisasi ini dalam memberikan pelayanan jasa kesehatan yang berkualitas dan memuaskan.

Pencapaian tujuan organisasi itu sendiri tidak lepas dari aktivitas manajemen organisasi tersebut dan juga oleh individu-individu yang terlibat di dalamnya. Setiap individu dalam hidupnya memiliki keinginan, baik itu keinginan akan materi, kesehatan, kebahagiaan, atau yang lainnya. Guna memenuhi berbagai keinginan tersebut individu dituntut untuk bekerja keras agar mampu mencapai tujuannya yaitu terpenuhinya keinginan hidup individu tersebut. Individu akan dapat mencapai tujuannya apabila mempunyai semangat kerja yang tinggi sehingga bekerja dengan lebih giat dan lebih baik.Semangat kerja karyawan yang tinggi akan membantu organisasi dalam mewujudkan pencapaian tujuannya. Lateiner (1980) menyatakan bahwa semangat kerja karyawan menentukan berhasil atau tidaknya pencapaian tujuan organisasi yang berlaku pada setiap bentuk organisasi.

Semangat kerja merupakan aktivitas melakukan pekerjaan secara lebih giat, sehingga dengan demikian pekerjaan akan dapat diharapkan lebih cepat dan lebih baik (Nitisemito, 1994). Pekerjaan yang dilakukan secara giat dan lebih baik sehingga pekerjaan menjadi cepat selesai serta ongkos per unit dapat diperkecil juga diartikan sebagai semangat kerja oleh
Anoragan\& Widiyanti (1990). Banyak tokoh yang mendefinisikan semangat kerja, diantaranya seperti yang dikemukakan oleh Flippo (1995) bahwa semangat kerja didefinisikan sebagai keadaan mental atau sikap dari perilaku individu dan kelompok yang bersedia bekerja sama dengan lebih giat. Moekijat (1991) juga mengartikan semangat atau moril kerja itu sebagai kemampuan sekelompok orang-orang untuk bekerja sama dengan giat dan konsekuen dalam mengejar tujuan bersama. Pendapat senada juga dikemukakan oleh Siswanto (1999) yang memaparkan bahwa semangat kerja adalah kemampuan seseorang untuk bekerja sama dengan giat dan konsekuen dalam mencapai tujuan yang telah ditetapkan oleh perusahaan.

Halsey (1993) berpendapat bahwa semangat kerja adalah sikap kesediaan yang memungkinkan seorang pekerja untuk menghasilkan kerja yang lebih baik dan lebih giat tanpa menambah keletihan yang menyebabkan dia dengan antusias ikut serta di dalam kegiatan-kegiatan dan usaha-usaha kelompok sekerjanya dan yang membuat dia tidak mudah kena pengaruh di luar.Semangat kerja sebagai suasana batin seorang yang berpengaruh pada usahanya mewujudkan suatu tujuan melalui pelaksanaan pekerjaan yang menjadi tanggung jawabnya (Nawawi,1990). Berdasarkan pemaparan definisi oleh para ahli di atas maka dapat disimpulkan bahwa semangat kerja adalah sikap atau mental atau kesediaan seseorang dan kesukarelaannya dalam bekerja sama untuk melakukan pekerjaannya dengan lebih 
baik dan mencurahkan kemampuannya secara total atau menyeluruh, dengan giat dan penuh antusias dalam mengerjakan tugas-tugas perusahaan, yang mana nantinya akan berdampak pada meningkatnya produktivitas kerja (Flippo, 1995; Halsey, 1993; Nitisemito, 1994; Siswanto, 1999; Westra, 1996).

Semangat yang tinggi dalam melakukan pekerjaan akan membuat individu tidak akan memperhatikan rasa lelah atau jenuh saat individu tersebut bekerja. Menurut Kholiq (2001), ada beberapa aspek semangat kerja, yaitu : 1). kegairahan (meliputi rasa capek, mengantuk, pikiran lebih segar, lebih santai, giat bekerja, tidak bekerja dengan cepat, tidak bekerja dengan ajeg.) ;2). kualitas untuk bertahan (meliputi: jenuh dengan pekerjaan, mencoba pekerjaan lain, suka bekerja disini); 3). kekuatan untuk melawan frustasi (meliputi: melakukan banyak kesalahan, mau menerima kritikan, tidak melaksanakan kritikan); dan 4). semangat berkelompok (meliputi: bekerja sama dalam kelompok kerja).

Semangat kerja berkaitan dengan ketulusan hati karena adanya kepuasan kerja sebagai akibat terpenuhinya kebutuhan dasar dari pekerjaan yang dilakukan. Artinya, bahwa karyawan yang kebutuhan dasarnya terpenuhi dari pekerjaannya maka ia akan memperoleh kepuasan kerja. Kepuasan kerja mempengaruhi semangat kerja, sehingga individu bekerja dengan lebih giat dan dengan hati yang tulus dalam menjalankan pekerjaannya.

Kehadiran, kelambanan, antusiasme, kerjasama merupakan indikator-indikator penting untuk mengukur semangat kerja. Perusahaan atau organisasi akan memperoleh keuntungankeuntungan tertentu jika karyawannya mempunyai semangat kerja, keuntungan yang diperoleh antara lain adalah pekerjaan yang bisa lebih cepat diselesaikan, kerusakan akan dapat dikurangi, absensi akan dapat diperkecil, perpindahan karyawan dapat diperkecil, produktivitas kerja dapat ditingkatkan, dan ongkos perunit dapat diperkecil (Nitisemito, 1994).

Perawat yang juga berkedudukan sebagai karyawan pada suatu rumah sakit dituntut untuk bisa melakukan pekerjaannya dengan lebih cepat dan lebih baik. Mereka harus memberikan pelayanan kesehatan terhadap setiap pasien dengan cepat dan tepat. Pelayanan kesehatan tersebut menggambarkan bahwa pelaksanaan asuhan keperawatan di rumah sakit tersebut dapat berjalan secara optimal sehingga tujuan organisasi pun dapat terwujud.

\section{Keterkaitan Semangat Kerja terhadap Pelaksanaan Asuhan Keperawatan}

Pelaksanaan asuhan keperawatan oleh seorang perawat merupakan tindakan yang sangat penting peranannya dalam membantu klien menyelesaikan masalah kesehatannya. Perilaku caring, humanistik, dan holistik harus selalu mendasari perilaku perawat dalam memberikan asuhan keperawatan yang profesional kepada klien. Seperti yang ditekankan oleh Chitty (dalam Nursalam 2002) bahwa nilai-nilai ilmu keperawatan ditekankan pada tiga unsur utama, yaitu: holistik, humanistik, dan care dengan 
menekankan pada upaya pemenuhan kebutuhan dasar manusia baik sehat maupun sakit dalam membantu meningkatkan, mencegah, mengembalikan fungsi kesehatan yang terganggu akibat kehilangan fungsi kesehatan karena sakit yang diderita sebagai objek ilmu perawatan.

Perawat profesional menjalankan beberapa peran dalam tugasnya sebagai perawat. Kusnanto (2004) menyebutkan bahwa peran seorang perawat professional meliputi: care giver (sebagai pemberi asuhan keperawatan), client advocate (sebagai pembela untuk melindungi klien), counselor (sebagai pemberi bimbingan atau konseling klien), educator (sebagai pendidik klien), collaborator(sebagai anggota tim kesehatan yang dituntut untuk dapat bekerja sama dengan tenaga kesehatan lainnya), coordinator (sebagai koordinator agar dapat memanfaatkan sumber-sumber dan potensi klien), change agent (sebagai pembaru yang selalu dituntut untuk mengadakan perubahan-perubahan), dan consultant(sebagai sumber informasi yang dapat membantu memecahkan masalah klien).

Perilaku caring merupakan kesediaan memperhatikan kesejahteraan orang lain termasuk kemurahan hati dan ketekunan yang di dalamnya terdapat sifat-sifat seperti sabar, jujur, dan rendah hati. Sobel mendefinisikan caring sebagai suatu rasa peduli, hormat dan menghargai orang lain (Wedho, 2005). Artinya bahwa perilaku caring memberi perhatian dan mempelajari kesukaankesukaan seseorang dan bagaimana seseorang berpikir, bertindak juga berperasaan.

Seorang perawat profesional harus mampu memiliki minat terhadap orang lain dan juga memiliki kepedulian terhadap kesehatan pasien sehingga mampu melakukan tindakan yang bermoral pada saat melakukan tugas pendampingan perawatan. Hal ini diungkapkan oleh Wedho (2005) bahwa caring sebagai suatu "moral imperative" (bentuk moral) sehingga perawat harus terdiri dari orang-orang yang bermoral baik dan memiliki kepedulian dan mempertahankan martabat serta menghargai pasien sebagai seorang manusia.

Keperawatan dengan landasan humanistik merupakan suatu sikap dan pendekatan yang memperlakukan pasien sebagai manusia yang mempunyai kebutuhan bukan sekedar sebagai seorang berpenyakit tertentu. Pelayanan yang diberikan pun langsung dan secara manusiawi. Pendekatan humanistik dalam prakteknya memperhitungkan semua hal yang diketahui tentang pasien yang meliputi pikiran, perasaan, nilainilai, pengalaman, kesukaan, perilaku dan bahasa tubuh. Wedho (2005) menyebutkan bahwa humanisme meyakini kebaikan dan nilai-nilai manusia sebagai suatu komitmen dalam bekerja untuk kemanusiaan. Contoh perilaku yang manusiawi adalah empati, simpati, terharu, dan menghargai kehidupan sehingga dapat menerima orang lain apa adanya.

Pendekatan holistik dalam keperawatan meliputi pelayanan yang bersifat humane yang mencakup aspek-aspek bio-psiko-sosial/kultural dan spiritual pasien melalui proses 
komunikasi. Melalui pendekatan ini secara biologis pasien diberi obatobatan yang sesuai dengan penyakit yang dideritanya, secara psikologis pasien ditanya tentang perkembangan dari penyakit yang dideritanya, secara sosial/kultural pasien di ajak untuk saling berinteraksi dengan pasien lain baik yang mengalami penyakit sama maupun yang berbeda penyakit, kemudian secara spiritual pasien disarankan untuk lebih mendekatkan diri kepada Tuhannya untuk kesembuhan penyakitnya. Seperti yang dijabarkan oleh Kusnanto (2004), bahwa keperawatan merupakan bentuk pelayanan profesional yang merupakan bagian integral dari pelayanan kesehatan, didasarkan pada ilmu dan kiat keperawatan yang berbentuk pelayanan bio-psiko-sosial-spiritual yang komprehensif, ditujukan pada individu, keluarga dan masyarakat baik sakit maupun sehat yang mencakup seluruh proses kehidupan manusia.

Pelaksanaan asuhan keperawatan dengan landasan caring, holistik, dan humanis itulah klien akan merasa menjadi rekan atau teman dekat perawat sehingga klien dapat merasa nyaman dan menjadi terbuka terhadap suasana dan kondisi diri klien dengan begitu perawat pun akan mudah memperoleh informasiinformasi yang dibutuhkan untuk dapat membantu klien untuk mandiri dalam menyelesaikan masalahmasalahnya, sehingga tujuan pelaksanaan asuhan keperawatan dapat tercapai. Menurut Ali (2002) bahwa tujuan asuhan keperawatan adalah membantu klien untuk mandiri, mengajak klien atau masyarakat berpartisipasi dalam bidang kesehatan, membantu klien mengembangkan potensi untuk memelihara kesehatan secara optimal agar tidak tergantung pada orang lain dalam memelihara kesehatannya, dan membantu klien memperoleh derajat kesehatan optimal.

Setiap perawat mempunyai kewajiban moral membantu klien dalam mengatasi dan menyelesaikan masalah-masalah klien, yang kemudian kewajiban-kewajiban itu terpaparkan di dalam asuhan keperawatan, mulai dari tahap pengkajian, diagnosa, perencanaan, implementasi dan evaluasi. Seperti yang dipaparkan oleh Doenges (1998) bahwa proses asuhan keperawatan terdiri atas lima tahap yaitu pengkajian keperawatan, diagnosa keperawatan, perencanaan keperawatan, impementasi keperawatan, dan evaluasi keperawatan.

Tahap pengkajian keperawatan merupakan tahap pertama dalam proses asuhan keperawatan. Di tahap ini perawat melakukan pengumpulan data tentang status kesehatan klien secara sistematis, menyeluruh, akurat, singkat dan berkesinambungan. Tahap kedua dalam proses asuhan keperawatan adalah diagnosa keperawatan atau identifikasi masalah.Perawat menganalisis data pengkajian yang telah dikumpulkan untuk merumuskan diagnosa keperawatan.Kriteria proses pada tahap ini adalah proses diagnosa tersebut terdiri dari analisis, interpretasi data, identifikasi masalah klien dan perumusan diagnosis keperawatan. Kriteria proses berikutnya yaitu komponen diagnosis 
keperawatan terdiri dari: Masalah (P), penyebab (E), dan tanda atau gejala (S), atau terdiri dari masalah dan penyebab (PE). Kemudian kriteria proses berikutnya adalah bekerja sama dengan klien, dekat dengan klien, dan petugas kesehatan lain untuk memvalidasi diagnosis keperawatan. Kriteria proses terakhir di tahap ini adalah melakukan pengkajian ulang dan merevisi diagnosis berdasarkan data terbaru.

\section{Tahap ketiga dalam proses asuhan keperawatan adalah melakukan perencanaan.Perawat membuat rencana tindakan keperawatan untuk mengatasi masalah dan meningkatkan kesehatan klien. Ada empat kriteria proses perencanaan, yaitu: 1). Perencanaan terdiri dari penetapan prioritas masalah, tujuan dan rencana tindakan keperawatan; 2). Bekerja sama dengan klien dalam menyusun rencana tindakan keperawatan; 3). Perencanaan bersifat individual sesuai dengan kondisi atau kebutuhan klien; 4). Mendokumentasikan rencana keperawatan.}

Tahap berikutnya dalam proses asuhan keperawatan adalah implementasi. Perawat mengimplementasikan tindakan yang telah diidentifikasi dalam rencana asuhan keperawatan.Kriteria proses di tahap ini, antara lain: 1). Bekerja sama dengan klien dalam pelaksanaan tindakan keperawatan; 2). Kolaborasi dengan profesi kesehatan lain untuk meningkatkan status kesehatan klien; 3). Melakukan tindakan keperawatan untuk mengatasi masalah kesehatan klien; 4). Melakukan supervisi terhadap tenaga pelaksana keperawatan dibawah tanggung jawabnya; 5). Menjadi koordinator pelayanan dan advokasi terhadap klien untuk mencapai tujuan kesehatan; 6). Menginformasikan kepada klien tentang status kesehatan dan fasilitas-fasilitas pelayanan kesehatan yang ada; 7). Memberikan pendidikan pada klien dan keluarga mengenai konsep, keterampilan asuhan diri serta membantu klien memodifikasi lingkungan yang digunakannya; dan 7). Mengkaji ulang dan merevisi pelaksanaan tindakan keperawatan berdasarkan respon klien.

Tahap terakhir dalam proses asuhan keperawatan adalah evaluasi. Di tahap ini perawat mengevaluasi kemajuan klien terhadap tindakan dalam pencapaian tujuan dan merevisi data dasar serta perencanaan. Ada lima kriteria proses di tahap ini, antara lain: 1). Menyusun perencanaan evaluasi hasil dari intervensi secara komprehensif, tepat waktu dan terus menerus; 2). Menggunakan data dasar dan respon klien dalam mengukur perkembangan kearah pencapaian tujuan; 3). Memvalidasi dan menganalisis data baru dengan sejawat dan klien; 4). Bekerja sama dengan klien, keluarga untuk memodifikasi rencana asuhan keperawatan; 5). Mendokumentasikan hasil evaluasi dan memodifikasi perencanaan.Proses keperawatan menyediakan pendekatan pemecahan masalah yang logis dan teratur untuk memberikan asuhan keperawatan sehingga kebutuhan pasien dipenuhi secara komprehensif dan efektif (Ali, 2002).

Banyak faktor yang dapat mempengaruhi tindakan seorang perawat dalam melaksanakan asuhan 
keperawatan secara optimal. Menurut Lismidar (1990) bahwa faktor-faktor yang mempengaruhi tindakan seorang perawat diantaranya adalah faktor kepribadian perawat tersebut, kecakapannya, pengetahuan tentang pekerjaannya, inisiatif dalam melakukan pertolongan, dan lain-lain.

Hal-hal tersebut di atas memberikan kontribusi yang besar dalam pelaksanaan asuhan keperawatan secara optimal terhadap seorang klien, yang juga menggambarkan bagaimana produktivitas seorang perawat dalam menjalankan tugasnya sebagai perawat sehingga menghasilkan suatu pelayanan kesehatan yang berkualitas. Menurut Purwanto (2007) bahwa kualitas pelayanan kesehatan adalah sikap profesional perawat yang memberikan perasaan nyaman, terlindungi pada diri setiap pasien yang sedang menjalani proses penyembuhan dimana sikap ini merupakan kompensasi sebagai pemberi layanan dan diharapkan menimbulkan perasaan puas pada diri pasien. Makin sempurna kepuasan tersebut, makin baik pula kualitas pelayanan kesehatan.

Kualitas pelayanan kesehatan merupakan optimalisasi suatu asuhan keperawatan yang menggambarkan produktivitas kerja perawat dimana, optimalisasi tersebut disebabkan karena adanya semangat kerja seorang perawat dalam menjalankan tugas dan kewajibannya. Nitisemito (1994) menyebutkan bahwa salah satu keuntungan dari semangat kerja adalah meningkatnya produktvitas karyawan.
Menurut Halsey (1993) bahwa sikap kesediaan yang memungkinkan seorang pekerja untuk menghasilkan kerja yang lebih baik dan lebih giat tanpa menambah keletihan yang menyebabkan dia dengan antusias ikut serta di dalam kegiatan-kegiatan dan usaha-usaha kelompok sekerjanya dan yang membuat dia tidak mudah kena pengaruh di luar merupakan semangat kerja. Semangat kerja yang tinggi akan menghasilkan produktivitas yang tinggi pula dengan begitu optimalisasi asuhan keperawatan pada suatu rumah sakit akan dapat terwujud. Kondisi semangat kerja menjadikan individu semakin cepat dalam mendapatkan hasil akhir dari kerja yang telah ia lakukan. Individu kerapkali dihadapkan pada pekerjaan-pekerjaan yang harus mereka lakukan, mau tidak mau, suka ataupun tidak suka, dan tanpa semangat untuk melakukan pekerjaan yang kurang sesuai dengan kemampuan dan minat individu akan memberikan hambatan, bahkan frustasi dalam bekerja. Situasi ini membuat individu seringkali kehilangan semangat kerjanya, sehingga produktivitasnya menurun.

Anoragan (1992), menyatakan bahwa ada dua faktor yang mempegaruhi semangat kerja seseorang yaitu : faktor intern (terdiri dari kepribadian dan kehidupan emosional); dan faktor ekstern (terdiri dari lingkungan rumah, kehidupan kekeluargaan, dan lingkungan kerja). Individu yang memiliki semangat kerja yang baik tentu akan dengan mudah dalam menjalankan dan menyelesaikan tugas-tugas pekerjaannya. Faktor-faktor yang yang dapat dijadikan sebagai 
pedoman untuk meningkatkan semangat kerja karyawan menurut Nitisemito (1994) dan Aniek (dalam Purwanto, 2007) adalah gaji yang cukup, kebutuhan rohani yang terpenuhi, terciptanya suasana santai pada waktu-waktu tertentu di dalam jam pekerjaan, perasaan aman menghadapi masa depan, karyawan mempunyai loyalitas pada perusahaan, karyawan diajak berunding pada waktu tertentu, pemberian insentif yang terarah, memperhatikan harga diri karyawan, penempatan karyawan pada posisi yang tepat, adanya kesempatan untuk maju bagi semua karyawan, fasilitas yang menyenangkan, kerja sama dari teman sekerja, pengawasan atasan, dan kondisi kerja.

\section{Hipotesis}

$\mathrm{Ha}$ : Ada pengaruh semangat kerja terhadap pelaksanaan asuhan keperawatan di rumah sakit umum kolaka sulawesi tenggara

Ho : Tidak ada pengaruh semangat kerja terhadap pelaksanaan asuhan keperawatan di rumah sakit umum kolaka sulawesi tenggara

\section{METODE PENELITIAN}

Populasi dalam penelitian ini adalah semua perawat yang bekerja di Rumah Sakit Umum Kolaka Sulawesi Tenggara yang telah berstatus PNS. Jumlah populasi yang ada adalah sebanyak 150 perawat. Pengambilan sampel dilakukan dengan menggunakan teknik purposive random sampling. Kriteria responden dalam penelitian ini adalah bekerja aktif di RSUD Kolakaminimal 1 tahun, tidak sedang cuti, dan mengikuti shift pagi, sore, dan malam. Total responden yang memenuhi kriteria sampel sebanyak 75 subjek, namun data responden yang bisa diolah lebih lanjut dalam proses penelitian ini adalah 53 subjek.

Alat ukur yang digunakan dalam penelitian ini adalah skala. Ada dua skala yang digunakan dalam penelitian ini yaitu skala asuhan keperawatandan skala semangat kerja.

Penelitian ini didesain secara kuantitatif dan analisis yang digunakan dalam penelitian ini adalah analisis regresi linear sederhana dan program SPSS 11,0 digunakan untuk menganalisis datayang ada dalam penelitian ini. Analisis regresi digunakan untuk mengetahui bagaimana variabel independen/ prediktor, secara individual (Sugiyono, 2007).

\section{HASIL DAN PEMBAHASAN}

Data-data yang diperoleh dari penelitian ini selanjutnya dianalisis dengan menggunakan teknik analisis regresi linear sederhana. Hasil pengujian data yang pertama adalah menguji hipotesis penelitian yang dapat dilihat pada tabel 1 berikut: 
Tabel. 1

Ringkasan Hasil Pengujian Hipotesis

\begin{tabular}{ccccc}
\hline $\mathrm{F}$ & $\mathrm{F}_{\text {tabel }}$ & Signifikan & Keterangan & Kesimpulan \\
\hline 9,459 & 4,02 & 0,003 & Sig $<0,05$ & Signifikan \\
\hline
\end{tabular}

Tabel di atas menunjukkan nilai $F_{\text {hitung }}=9,459$ dengan tingkat signifikansi 0,003 , untuk $\mathrm{N}=53$. Probabilitas $(0,003)$ jauh lebih kecil dari 0,05 (taraf signifikan yang digunakan $5 \%$ ). Nilai $F$ hitung $(9,459)>$ nilai $F$ tabel $(4,02)$ yang artinya bahwa ada pengaruh antara semangat kerja dengan pelaksanaan asuhan keperawatan. Besar pengaruh semangat kerja terhadap pelaksanaan asuhan keperawatan $\left(\mathrm{R}^{2} \mathrm{x} 100\right)=$ $15,6 \%$.

Tabel. 2

Hasil Analisis Regresi

\begin{tabular}{cccc}
\hline $\mathrm{R}$ & $\mathrm{R}^{2}$ & $\begin{array}{c}\text { Adjusted } \\
\mathrm{R}^{2}\end{array}$ & $\begin{array}{c}\text { Std. Error } \\
\text { of the } \\
\text { Estimate }\end{array}$ \\
\hline 0,396 & $0,156^{\mathrm{a}}$ & 0,140 & 9,597 \\
\hline
\end{tabular}

a. predictors: (Constant), Semangat Kerja

Tabel di atas menunjukkan bahwa semangat kerja memiliki hubungan dengan pelaksanaan asuhan keperawatan yaitu $R=0,396$ dengan arah hubungan positif, rtabel sebesar 0,266 yang berarti $r_{x y}$ $(0,396)>r_{\text {tabel }}(0,266)$. Hal ini menunjukkan bahwa semakin tinggi semangat kerja yang dimiliki oleh perawat maka pelaksanaan asuhan keperawatan yang dilakukan oleh perawat makin baik atau optimal, begitupun sebaliknya. Selanjutnya, tabel di atas juga menunjukkan pengaruh semangat kerja terhadap pelaksanaan asuhan keperawatan bahwa $\mathrm{R}^{2}$ atau koefisien determinasi adalah 0,156 artinya $15,6 \%$ dari pelaksanaan asuhan keperawatan dipengaruhi oleh semangat kerja.

Hasil analisis di atas menunjukkan bahwa hipotesis yang menyatakan ada pengaruh yang signifikan antara semangat kerja terhadap pelaksanaan asuhan keperawatan diterima.

Berdasarkan hasil analisa data dalam penelitian ini diketahui bahwa pelaksanaan asuhan keperawatan di Rumah Sakit Umum Kolaka Sulawesi Tenggara dipengaruhi oleh semangat kerja para perawat.Pelaksanaan asuhan keperawatan akan optimal diberikan oleh perawat kepada pasien jika mereka mempunyai semangat kerja yang tinggi, begitupun sebaliknya. Optimalisasi pelaksanaan asuhan keperawatan akan memberikan dampak yang baik bagi rumah sakit yaitu terciptanya pelayanan kesehatan yang baik dan berkualitas. Purwanto (2007) mengungkapkan bahwa kualitas pelayanan kesehatan yang berkualitas adalah sikap profesional perawat yang memberikan perasaan nyaman, terlindungi pada diri setiap pasien yang sedang menjalani proses penyembuhan dimana sikap ini merupakan kompensasi sebagai pemberi layanan dan diharapkan menimbulkan perasaan puas pada diri pasien. Pencapaian kualitas pelayanan tersebut tidak luput dari 
adanya semangat kerja yang tinggi dari para perawat dalam menjalani tugas-tugasnya.

Salah satu dampak dari menurunnya semangat kerja adalah meningkatnya kemangkiran karyawan atau meningkatnya absen karyawan yang jelas merugikan instansi. Menurut Anoragan (1992) bahwa semangat kerja seorang karyawan dipengaruhi oleh dua faktor, yaitu antara lain: (1). Faktor intern, terdiri dari kepribadian dan kehidupan emosional; dan (2). Faktor ekstern, terdiri dari lingkungan rumah, kehidupan kekeluargaan, dan lingkungan kerja.

Secara keseluruhan dari penelitian ini diketahui bahwa semangat kerja memiliki pengaruh sebesar $15,6 \%$ terhadap pelaksanaan asuhan keperawatan, sedangkan sisanya yaitu $84,4 \%$ atau 0,844 dipengaruhi oleh faktor-faktor lain seperti motivasi kerja, kejenuhan kerja (burnout), beban kerja, komitmen kerja, self efficacy, dan faktor lainnya.

$\begin{array}{rrr}\text { Faktor dominan } & \text { yang } \\ \text { memberikan } & \text { sumbangan }\end{array}$ terhadap pelaksanaan asuhan keperawatan adalah motivasi kerja. Hal ini telah dibuktikan melalui penelitian lain yang telah dilakukan oleh Gunaya (2005) dimana hasil penelitian tersebut menunjukkan bahwa persepsi terhadap beban kerja, komitmen kerja dan tingkat motivasi berpengaruh terhadap pelaksanaan asuhan keperawatan. Dan berdasar uji statistik diperoleh hasil bahwa yang paling dominan mempengaruhi pelaksanaan asuhan keperawatan adalah tingkat motivasi. Penelitian lainnya juga menyebutkan bahwa pemberian motivasi benar-benar meningkatkan sikap perawat dalam memberikan asuhan keperawatan (Yusuf, 2004).Semangat kerja karyawan yang tinggi akan membantu organisasi dalam mewujudkan pencapaian tujuannya. Lateiner (1980) menyatakan bahwa semangat kerja karyawan menentukan berhasil atau tidaknya pencapaian tujuan organisasi yang berlaku pada setiap bentuk organisasi, sebagaimana yang ada di rumah sakit Rumah Sakit Umum Kolaka Sulawesi Tenggara.

\section{KESIMPULAN}

Dari hasil pengumpulan data dan analisis data penelitian, serta diperkuat dengan dasar teori yang telah dipaparkan, maka diperoleh suatu simpulan bahwa ada pengaruh semangat kerja terhadap pelaksanaan asuhan keperawatan di Rumah Sakit Umum Kolaka Sulawesi Tenggara.

Pengaruh semangat kerja terhadap pelaksanaan asuhan keperawatan cukup kecil karena masih ada faktor-faktor lain yang cukup dominan diluar penelitian ini yang dapat mempengaruhi pelaksanaan asuhan keperawatan seperti, motivasi kerja.

\section{DAFTAR PUSTAKA}

Ali, H. Z. 1999. Dasar-dasar Keperawatan Profesional. Jakarta: Widya Medika.

\section{Pengantar}

Keperawatan. Jakarta: Widya Medika.

Anoragan, P. 1992. Psikologi Kerja. Jakarta: PT. Rineka Cipta. 
dan Widiyanti, N. 1990.

Psikologi dalam Perusahaan. Jakarta: PT. Rineka Cipta.

Doenges, M. E. Dkk. 1998. Penerapan Proses

Keperawatan dan Diagnosa Keperawatan. Jakarta: Penerbit Buku Kedokteran.

Flippo, E. B. 1995. Manajemen Personalia. Jakarta: Erlangga.

Gunaya, I N. D. 2005. Asuhan Keperawatan. Diunduh dari www.unair.ac.id

Halsey, George. D. 1993. Bagaimana Memimpin dan Mengawasi Pegawai Anda. Jakarta: M. Aksara.

Kusnanto. 2004. Pengantar Profesi dan Praktik Keperawatan Profesional. Jakarta: Penerbit Buku Kedokteran.

Lismidar, H. dkk. 1990. Proses Keperawatan. Jakarta: Universitas Indonesia Press.

Lateiner, A. R. 1980. Teknik Memimpin Pegawai dan Pekerja. Terjemahan Imam Soejono. Jakarta: Aksara Baru.

Moekijat. 1991. Manajemen Kepegawaian. Bandung: Penerbit Alumni Bandung.

Nawawi, H. Hadari. 1990. Manajemen Sumber Daya Manusia untuk Bisnis yang
Kompetitif. Yogyakarta: UGM Press.

Nitisemito, A. S. 1994. Manajemen Personalia. Jakarta: Ghalia Indonesia.

Nursalam. 2002. Manajemen Keperawatan. Jakarta: Salemba Medika.

Purwanto. 2007. Sikap Kerja Perawat. Diunduh dari http://klinis.wordpress.com

Riyanto, S. 2002. Pengaruh Lingkungan Fisik Kerja, Kesejahteraan, Motivasi, dan Koordinasi Terhadap Semangat Kerja Karyawan Rumah Sakit Umum Daerah Kabupaten Kudus. Semarang: Universitas Diponegoro. Tesis tidak diterbitkan.

Siswanto, B. 1999. Manajemen Tenaga Kerja. Bandung: Sinar Baru.

Sugiyono. 2007. Statistika untuk Penelitian. Bandung: CV. Alfabeta.

Wedho. 2005. Caring, humanis, holistik. www. klinis. wordpress.com.

Westra, P. 1996. Beberapa Masalah di dalam Hubungan Kerja Kemanusiaan. $\quad$ Yogyakarta: Balai Pendidikan Administrasi UGM. 